\title{
Regionális bérjövedelem-különbségek a gazdaságtudományi területen végzett frissdiplomások esetében
}

\author{
Regional wage income differences for fresh graduates \\ in economics
}

\section{SZABÓ DOROTTYA ANNA}

SZABó Dorottya Anna: mesterképzéses hallgató, Pécsi Tudományegyetem Közgazdaságtudományi Kar; 7622 Pécs, Rákóczi út 80.; szabodotti@gmail.com; https://orcid.org/ 0000-0002-8422-0953

KULCSSZAVAK: bérjövedelem; Frissdiplomások adatbázis; regionális különbségek

ABSZTRAKT: A munkabér nagysága meghatározza az egyén életszínvonalát, ennek révén befolyásolja boldogságát, jóllétét, amely a társadalom egészét tekintve szoros kapcsolatban áll a gazdaság fejlettségével is . A munkajövedelem erősen függ az egyes személyek humán tőkéjének (felhalmozott tudás és képességek) nagyságától, azonban számos egyéb tényező is befolyásolja, mint például a nem, a beosztás vagy a munkahely regionális elhelyezkedése. Az alapvető kutatási kérdés az, hogy milyen mértékben határozza meg az frissdiplomás közgazdászok bérezését munkahelyük székhelyének regionális elhelyezkedése. A Diplomás Pályakövetési Rendszer Frissdiplomások 2011-2015-ös felméréseinek szürt, 12429 adatsorból álló adatbázisát az SPSS program segítségével elemeztem. Az egyutas varianciaanalízis eredményei alapján a Közép-Dunántúl és a Közép-Magyarország régiók fizetésadatai szignifikánsan eltérnek egymástól és a többi régiótól is. Lineáris regressziós modellek létrehozásával kiderült, hogy önmagában a regionális elhelyezkedés 14,4 százalékban magyarázza a bérek alakulását, és hatását leginkább a további munkaerőpiaci tényezők (például beosztás, munkahely mérete) tudják csökkenteni. A munkaerőpiaci, tanulmányi (például tagozat, finanszírozási forma, tanulmányi eredmény, nyelvismeret), és szociodemográfiai (például nem, szülők végzettsége) változókat is tartalmazó modell magyarázóereje $53 \%$ lett, a regionális hatás jelentősége szignifikáns és erős maradt a bérek nagyságának szempontjából. Ezen modell szerint Közép-Magyarország régióját referenciakategóriának véve a további régiókban minden más változó változatlansága mellett 13,0-18,2 százalékkal voltak alacsonyabbak a nettó bérek.

Anna Dorottya SZABÓ: master student, Faculty of Business and Economics, University of Pécs; Rákóczi u. 80., H-7622 Pécs, Hungary; szabodotti@gmail.com; https://orcid.org/0000-0002-8422-0953

KEYWORDS: wage income; Fresh Graduates database; regional differences

ABSTRACT: The wage level determines an individual's standard of living and influences his or her happiness and well-being. At the societal level, individual well-being is closely linked to the development of the economy. Wage level is highly dependent on an individual's human capital (accumulated knowledge and skills), but it is also influenced by a number of other factors, such as gender, position, or regional location of the workplace. I conducted my research focusing on the examination of the latter factor. I made hypotheses about the presence, strength, and lasting effect of regional pay disparities by also involving other influencing factor sets.

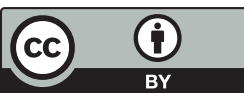


The main question of my research was to what extent does the regional location of the place of work determine the wages of recent graduates in economics and whether there are significant differences between regions. I analyzed the filtered database of the Fresh Graduates 2011-2015 of the Graduate Career Tracking System through the SPSS program. The final sample of fresh economics graduates is 12,429 .

Based on the results of the One-Way ANOVA, the wage data of the Central Transdanubia and Central Hungary regions differ significantly from each other and from the other regions as well. This suggests that the region of Central Hungary, which includes Budapest and Pest county, has the highest net salaries for fresh graduates included in the analysis. With the creation of OLS linear regression models, it turned out that the regional location alone explains wage differences by 14.4\%, and the net wages in each Hungarian region are 17.3-23.0\% lower than in the Central Hungary region. Including additional variables, the regional impact was reduced the most by labor market factors (e.g., location, organizational size, position), ceteris paribus, the wages are 11.218.2\% lower than in the reference category (Central Hungary). The explanatory power of the extended model, where multiple factors exert their effect, including labor market, study-related (e.g., type of education, the form of financing, academic performance, language skills), and sociodemographic variables (e.g., gender, parents' education, the financial situation of the family), became 53\%, and the significance of the regional impact remained strong in terms of wage levels. According to this model, still using the region of Central Hungary as the reference category, the net salaries of fresh graduates in economics ceteris paribus are 10.2-17.1\% lower in the other regions.

\section{Bevezetés}

Mivel a megszerzett bérjövedelem jelentősen befolyásolja az egyének életszínvonalát, fontos kérdés, hogy milyen tényezők határozzák meg a bérek nagyságát, és azok hogyan növelhetők. A munkabér az emberi tőkéért járó fizetség, fontos tehát az emberi tőkébe való befektetés, például az oktatásban való részvétel által. Ugyanakkor számos más tényező is okozhat eltéréseket az egyes személyek munkajövedelmei között, mint például a nem, az életkor, vagy az általam vizsgált regionális különbségek.

A jövedelem, a pénz és a boldogság között pozitív szignifikáns kapcsolat van, tehát a bérjövedelem mértéke meghatározza az egyén életszínvonalát, anyagi biztonságát (Cummins 2000; Frey, Stutzer 2001; Furnham, Argyle 1998; Dilworth et al. 2000). Bár a pénz önmagában nem feltétlenül boldogít, a kutatások szerint a magasabb jövedelemnek egy bizonyos mértékig szerepe van az emberek boldogságában, azonban csökkenő határhaszonnal és nem közvetlenül, hanem saját szubjektív megítélésünkön keresztül (Cummins 2000; Katona 2019; Meixner 2011). Stevenson és társai (2010) kutatása szerint erős pozitív kapcsolat található a szubjektív jóllét és a gazdaság fejlettsége között is. Az egyének jövedelmét leginkább a munkabér határozza meg, mely elsősorban a humán tőkébe való beruházással növelhető. Az emberi tőke értékét növelő tényezőket T. W. Schultz (1961, 1983) öt kategóriába sorolta, ezek egyike a formális képzésben (alap-, közép- és felsőoktatás) és a felnőttképzési programokban való részvétel is.

Az oktatásban való részvétel azonban mind egyéni, mind állami szinten költségekkel jár, amelyek a beruházás áraként is értelmezhetőek. Az egyes szemé- 
lyek számára a saját humán tőkéjükbe való befektetésük megtérülése függhet az időtől, mivel a humán tőke élettartama maximum tulajdonosának élettartamával lehet egyenlő. Érdemes minél fiatalabb korban részt venni a képzéseken, mert amellett, hogy ekkor még alacsonyabb a kieső jövedelem, több idő marad a megtérülésre (Varga 1998). Pénzügyi értelemben az emberi erőforrásba fektetett költségek megtérülésének jó mérőszáma lehet a későbbiekben elérhető munkajövedelem nagysága. A humán tőke nagysága ugyan meghatározza a fizetés mértékét, más tényezők szerepe sem elhanyagolható. Kutatásom során ezen további tényezők hatását vizsgáltam meg a frissdiplomás (1-5 éve diplomázott) közgazdászok bérjövedelmének alakulására, különös tekintettel a regionalitásra, a munkahely székhelye regionális elhelyezkedésének szerepére.

\section{Bérjövedelem-különbségek a szakirodalomban}

\section{Bérjövedelem-különbségeket okozó tényezók}

A humán tőke nagyságán, illetve a képzésben való részvételen (képzettségen) kívül több tényező hozhat létre fizetésbeli különbséget az egyes munkavállalók között. Az eltérő pozícióban és szakmában foglalkoztatott emberek különböző mértékű pénzügyi juttatásban részesülnek a munkaerőpiacon, amit például az eltérő képzettség vagy a munka jellege okozhat. Az egyes személyek bérjövedelme között azonban egy szakmán, vagy akár egy munkahelyen és azonos pozíción belül is kialakulhatnak különbségek, melyek legfontosabb okai közé a nem, a munkatapasztalat, a meglévő tudás és a kompetenciák, vagy a munkahely mérete, típusa és iparága tartoznak. Eltérést eredményezhet a munkahely földrajzi elhelyezkedése, ugyanakkor egy országon belül, így regionális szinten is értelmezhetőek a bérjövedelem-különbségek.

Ami az iskolázottság szintje és a bérjövedelem közötti összefüggést illeti, a KSH (2018a) referenciaháztartások alapján végzett felméréséből látható, hogy a felsőfokú végzettséget, illetve az alapfokú, vagy annál alacsonyabb végzettséget szerző referenciaszemélyű háztartások között több mint háromszoros a bérjövedelem-különbség, és hogy tíz évvel korábban az eltérés mértéke több mint hatszoros volt. A felsőfokú képzettséggel rendelkező referenciaháztartások 2018-ban közel kétszer magasabb jövedelemmel rendelkeztek, mint azok, amelyekben a referenciaszemély középfokú végzettséggel rendelkezett.

Az egyes emberek eltérő mértékben rendelkeznek különböző kompetenciákkal, amelyek szintén alakíthatják a bérjövedelmet. Európában általában nagyobb fizetéssel lehet számolni a participatív (részvételi, pl. szervezés, asszertivitás, vezetői és tárgyalási) készségeket, illetve módszertani kompetenciákat (mint idegen nyelv tudása, kritikus gondolkodás, tanulási készségek) igénylő munkakörökben, a legalacsonyabb bérek pedig azokban a pozíciókban figyelhetők meg, amelyek 
szervezeti kompetenciákat (pl. pontosság, nyomás alatt végzett munka, időgazdálkodás) igényelnek (García-Aracil, Van der Velden 2007; Sipos et al. 2013). Sipos és munkatársai (2020) kutatása szerint a Pécsi Tudományegyetemen végzettek körében az általános és szervezeti kompetenciák nem befolyásolják a béreket, a társadalmi, érzelmi kompetenciák azonban 5,5 százalékkal, a módszertani kompetenciák megléte pedig 19,4 százalékkal növelik a végzettek bérjövedelmeit.

Napjaink egyik fontos törekvése, hogy a munkaerőpiacon elérhető bérek tekintetében ne lehessen meghatározó a munkavállaló neme. Noha az egyes országokban eltérő ütemű ez a folyamat, általában a különbségek csökkenését figyelhetjük meg. A PricewaterhouseCoopers 2017-es felmérése az OECD országokban vizsgálta a munkából származó jövedelem nemek közötti különbségeit. A kutatás szerint a legtöbb országban 50 éven belül, hazánkban 2102-re fog eltűnni ez a bérkülönbség. Magyarországon a nemek közötti átlagos bérkülönbség 2017-ben 16,6\% volt - az európai átlag ekkor 16,3\%. A 2018-as év adatait a következő oszlopdiagram (1.ábra) tartalmazza Magyarország (14,5\%), illetve a világ néhány másik országa esetében (PwC 2017; PwC 2020; Szabó 2017).

A nemek közötti átlagos bérszakadék (azaz a bruttó órabér közötti különbség) 2020-ban Európában 16\%, hazánkban 14,2\% (Európai Parlament 2020). Ahhoz képest, hogy az 1980-as években a nők keresete átlagosan a férfiak bérének 75 százaléka volt (Szabó-Morvai 2019), a jelenlegi adatok nagy előrelépésről tanúskodnak. Hiába ösztönzik azonban többek között uniós irányelvek a különbségek csökkentését, és tüzik ki célul az egyenlőség elvének érvényesítését, továbbra is jelen van az egyenlőtlenség. Ennek hátterében például az áll, hogy a nők családi okokból gyakran szakítják meg karrierjüket, nagyobb arányban dolgoznak az egyébként is rosszabbul fizetett ágazatokban, és jóval kevesebb a női, mint a férfi felső vezető (Európai Parlament 2020).

\section{1. ábra: Fizetésbeli különbségek a nemek között (2018)} Gender pay gap (2018)

Férfiak és nők közötti bérszakadék 2018 (\%)

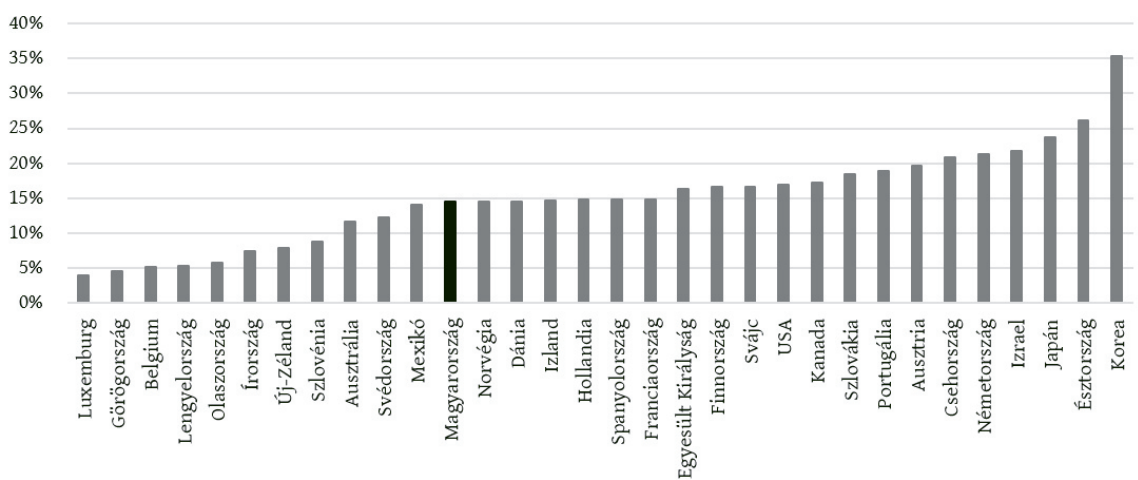

Forrás: PwC 2020, saját szerkesztés 
Magyarországon ugyan alapvetően közelednek egymáshoz a bérek, az egyenlőség inkább az alacsony végzettséget igénylő szakmákban jelenik meg, a felsőfokú végzettséget igénylő szakmáknál a különbség sok esetben még növekedett is. 2017-ben a magyarországi 25-64 éves diplomás nők a férfiak fizetésének 67 százalékát keresték, s ez az arány az OECD 26 országa közül a második legalacsonyabb értéket mutatta. Az OECD átlaga ekkor 75\% volt, a magyarnál nagyobb különbséget csak Mexikó esetében mértek (Eduline 2019; OECD 2015).

A munkahely mérete és szektora befolyásolja a fizetések nagyságát. Míg a nagyvállalatok (legalább 250 foglalkoztatott) esetében az átlagos bér bruttó 300000 forint volt, a középvállalkozásoknál (50-249 foglalkoztatott) bruttó 250 000, a kisvállalkozásoknál (10-19, illetve 20-49 foglalkoztatott) bruttó 195-220 000, a mikrovállalatok (5-9 foglalkoztatott) esetében pedig bruttó 180000 forint volt az átlagos bejelentett bér 2017-ben (Rigó 2017). A legmagasabb bruttó átlagos jövedelem a pénzügyi és biztosítási tevékenységek szektorában érhető el, ám ettől nem sokkal marad el az információ, kommunikáció, illetve a villamosenergia-, gáz- és gőzellátás, légkondicionálás szektora. Különbség van az állami és a versenyszférában dolgozók bére között is. A legalacsonyabb átlagos kereset a vendéglátás, illetve a humán-egészségügyi, szociális ellátás nemzetgazdasági ágában volt 2019-ben (KSH, 2019).

\section{Regionális eltérések}

Fizetésbeli különbségek nem csak a különböző országok között, hanem azokon belül, régiónként, vagy akár településenként is léteznek. Kutatásom során kiemelten a Magyarország régiói közötti különbségekre fókuszáltam. Országunk nyolc tervezés-statisztikai régióra bontható, melyek a következőek: Nyugat-Dunántúl, Közép-Dunántúl, Dél-Dunántúl, Észak-Magyarország, Észak-Alföld, DélAlföld, Pest és Budapest. Pest és Budapest 2016-ban váltak önálló régióvá, addig együttesen Közép-Magyarország néven számítottak egy régiónak.

A regionális gazdasági teljesítmény jó mérőszáma az egy főre jutó regionális GDP nagysága, melynek értékében komoly különbségek mutatkoznak a hazai régiók között. Az egy före jutó bruttó hazai termék értéke 2010 és 2018 között mindvégig Budapesten (illetve a már megszünt, Budapestet is magába foglaló Közép-magyarországi régióban) volt a legmagasabb, ahogyan az egy háztartásra jutó bérjövedelem is ebben a régióban a legnagyobb (1. táblázat). Az egy főre jutó GDP a 2014-ig az ÉszakMagyarország, majd 2014 és 2018 között az Észak-Alföld régióban volt a legalacsonyabb, és ezzel összhangban az egy háztartásra jutó bérjövedelem is e két régióban volt a legkevesebb az időszak során (KSH 2018b; KSH 2020).

2012 és 2017 között a regionális egy főre jutó GDP növekedéséhez legnagyobb mértékben mindenhol a foglalkoztatási ráta növekedése járult hozzá, azonban az Észak-Magyarország, a Közép-Dunántúl és a Dél-Alföld régiókban jelentős volt a munkatermelékenység növekedése is (MNB 2020). A KSH (2018b) 
1. táblázat: Egy före jutó GDP régiónként (2010-2018)

GDP per capita by region (2010-2018)

\begin{tabular}{lccccccccc}
\multicolumn{1}{c}{ Keglo } & 2010 & 2011 & 2012 & 2013 & 2014 & 2015 & 2016 & 2017 & 2018 \\
\hline Közép-Magyarország & 4502 & 4619 & 4729 & 4865 & 5207 & 5396 & 5583 & 6073 & 6681 \\
Budapest & 6002 & 6194 & 6348 & 6458 & 6908 & 7100 & 7412 & 8155 & 8993 \\
Pest & 2402 & 2415 & 2422 & 2593 & 2773 & 2961 & 2995 & 3166 & 3496 \\
Közép-Dunántúl & 2378 & 2525 & 2550 & 2757 & 2999 & 3329 & 3508 & 3747 & 4134 \\
Nyugat-Dunántúl & 2805 & 2923 & 2971 & 3133 & 3516 & 3845 & 4008 & 4191 & 4512 \\
Dél-Dunántúl & 1851 & 1910 & 1985 & 2104 & 2194 & 2359 & 2469 & 2709 & 3066 \\
Észak-Magyarország & 1635 & 1705 & 1719 & 1883 & 2081 & 2369 & 2450 & 2764 & 3060 \\
Észak-Alföld & 1742 & 1863 & 1884 & 1954 & 2125 & 2267 & 2327 & 2566 & 2852 \\
Dél-Alföld & 1824 & 1927 & 2009 & 2162 & 2356 & 2573 & 2645 & 2867 & 3237 \\
\hline Magyarország & 2743 & 2858 & 2915 & 3062 & 3319 & 3549 & 3685 & 4008 & 4434 \\
\hline
\end{tabular}

Forrás:KSH (2020), saját szerkesztés

összes háztartás jövedelmét régiókénti tagolásban is tartalmazó adatai alapján jól látható, hogy a munkajövedelmek szempontjából legmagasabb, illetve legalacsonyabb összeget mutató régiók között egyes években közel kétszeres különbség is volt 2010 és 2016 között (2. táblázat).

A legmagasabb munkajövedelemhez a Közép-Magyarország régióban, azon belül is Budapesten juthattak a munkavállalók, de a következő két évben is Budapesten (immár önálló régióként) vihették haza a munkavállalók a munkából származó legnagyobb jövedelmet. A legrosszabbul a vizsgált időszak hét évében az észak-alföldi terület szerepelt, 2014-ben viszont Dél-Alföldön, 2015-ben pedig Észak-Magyarországon keresték a legkevesebbet a munkavállalók.

2010-ben az Észak-Alföld régió átlagos egy főre jutó jövedelme csupán 51 százaléka a budapesti értéknek, két kisebb visszaeséstől eltekintve (2012-ben és 2015-ben) azonban a különbség folyamatosan csökkent. 2018-ban az Észak-Alföld régióban az egy före jutó munkajövedelem 1,56 millió forint, Budapesten 2,34 millió

2. táblázat: Egy háztartásra jutó munkajövedelem régiónként

Labour income per household by region (2010-2018)

\begin{tabular}{llllllllll}
\multicolumn{1}{c}{ Régió } & 2010 & 2011 & 2012 & 2013 & 2014 & \multicolumn{1}{l}{2015} & \multicolumn{1}{l}{2016} & \multicolumn{1}{c}{2017} & 2018 \\
\hline Közép-Magyarország & 1013 & 1041 & 1039 & 1101 & 1097 & 1189 & 1230 & 1403 & 1552 \\
Budapest & 1131 & 1159 & 1234 & 1312 & 1305 & 1388 & 1437 & 1557 & 1711 \\
Pest & & & & & & & & 1194 & 1343 \\
Közép-Dunántúl & 734 & 802 & 834 & 943 & 964 & 1090 & 1141 & 1310 & 1542 \\
Nyugat-Dunántúl & 740 & 780 & 837 & 972 & 994 & 1060 & 1090 & 1365 & 1217 \\
Dél-Dunántúl & 603 & 659 & 688 & 710 & 810 & 847 & 990 & 1043 & 1124 \\
Észak-Magyarország & 617 & 652 & 653 & 727 & 835 & 826 & 875 & 916 & 1159 \\
Észak-Alföld & 577 & 625 & 637 & 719 & 752 & 759 & 855 & 954 & 1164 \\
Dél-Alföld & 651 & 689 & 745 & 809 & 897 & 938 & 975 & 1024 & 1250 \\
\hline
\end{tabular}

Forrás: KSH (2018b), saját szerkesztés

Megjegyzés: Budapest és Pest 2017-tól lettek különálló régiók ezért Pest esetében 2010-2016 között nincs adat. 
forint volt, ami már csak 1,5-szeres különbséget jelent. Ennek az az oka, hogy a régiókban eltérő ütemben változott az egy före jutó munkajövedelem összege. 2010 és 2018 között a legkisebb átlagos éves növekedés Budapesten/a korábbi Közép-Magyarország régiókban figyelhető meg (5,35\% és 5,59\%), leszámítva az immár különálló Pest régió 2017-2018 közötti 22,55 százalékos növekedését. Mindeközben a legalacsonyabb egy före jutó jövedelemmel rendelkező Észak-Alföld régióban az átlagos évenkénti növekedés 9,34\%. Ennél magasabb értékkel csak Közép-Dunántúl régió rendelkezik, a növekedés itt évente átlagosan közel 10\% volt. NyugatDunántúlon 6,87 százalékos az éves növekedés, a fennmaradó három régió értéke 8,2-8,64\% között áll (KSH 2018c).

A bérben és az egy főre jutó GDP-ben látható regionális eltéréseket többek közt a regionális termelékenységben, a foglalkoztatásban és az alacsonyabb vagy magasabb hozzáadott értékủ szegmensek arányában lévő különbségek okozhatják. 2017-ben a legmagasabb termelékenységi szint Budapesten (8,3 millió forint/ fö), a legalacsonyabb pedig az Észak-Alföld (6,8 millió forint/fó) és a Dél-Dunántúl (6,9 millió forint/fö) régiókban volt. 2010 és 2017 között igen nagy mértékben (2,3-2,8\%) tudott növekedni az éves átlagos reál munkatermelékenység a Közép-, és Nyugat-Dunántúl, illetve az Észak-Magyarország régiókban, melynek egyik oka 2010 után a foglalkoztatottság munkaerőpiaci reformoknak köszönhető növekedése, másik a feldolgozóipar bővülése volt (MNB 2020).

Azt, hogy valaki melyik régióban talál munkát, jó eséllyel befolyásolja, hogy melyik régióban folytatja felsőfokú tanulmányait. (A Pécsen alapképzésen a 2017-18-as tanévben végzett közgazdászok több mint 80 százaléka helyezkedett el a Dél-Dunántúl régióban, a Budapesti Corvinus Egyetem és a Budapesti Gazdasági Egyetem ugyanekkor végzett közgazdász hallgatóinak pedig körülbelül 65-70 százaléka Budapest / Pest régióban talált munkahelyet.) Ebből következően nem közömbös, hogy az adott régió milyen lehetőségeket kínál a fiataloknak (Diplomántúl.hu 2020). Kutatási tapasztalatok azt mutatják, hogy a leendő hallgatók a felsőoktatási intézmény kiválasztásakor figyelembe veszik azokat az adottságokat is, amelyeket a régió/megye biztosít; így például a bérszínvonalat, a hosszú távú munkalehetőségeket, a kulturális és szociális szolgáltatásokat, intézményeket. A felsőoktatás és a régió adottságai (szakkínálat, hallgatói rendezvények, infrastruktúra, illetve elhelyezkedési lehetőségek, munkaerőpiaci struktúra, gazdasági fejlettség) tehát valamilyen szinten erősítheti egymást (Lengyel, Rechnitzer 2004; Balogh 2015; Kuráth, Sipos 2019). 2017-ben a felsőoktatási jelentkezés során a diákok 53 százaléka valamelyik budapesti egyetemet jelölte meg első helyen, és ennek a régiónak a legnagyobb a megtartó ereje is (az adott régióban lakó felvételiző ugyanabba a régióba jelentkezik) (Kuráth, Sipos 2019). A regionális bérkülönbségek forrása a régiók eltérő gazdasági teljesítménye, az itt működő vállalatok mérete mellett a régióban elérhető oktatási kínálat is lehet. 


\section{Hipotézisek}

A regionális különbségek jelentőségére több kutatás felhívja a figyelmet. Lukács és Rácz (é.n.) kutatása rámutat arra, hogy 1994-2010 között végig a Közép-Magyarország régióban voltak a legmagasabbak az átlagos bruttó jövedelmek, míg a legalacsonyabban jellemzően az Észak- és Dél-Alföld régiókban. Kosztyán és társai (2020) arra következtetnek, hogy a frissdiplomások munkahelyválasztásában igen jelentős szerepe van az adott térségben elérhető bérezésnek, Oosterbeek és Webbink (2011) vizsgálata pedig arról tanúskodik, hogy a frissen végzett egyetemisták gyakran költöznek nagyobb, fejlettebb városokba a magasabb bér és megfelelőbb munkahelyválaszték miatt, a frissdiplomások tehát kifejezetten mobilnak számítanak (Corcoran, Faggian 2017). Ebből következően lényeges kérdés, hogy a frissdiplomások bérezését tekintve milyen mértékủ regionális eltérések mutatkoznak hazánkban.

Saját kutatásom során arra kerestem a választ, hogy a munkahely székhelyének regionális elhelyezkedése mennyiben befolyásolja a munkabért, illetve, hogy az olyan közismert különbséget generáló tényezők, mint a munkavállaló neme, milyen mértékben érzékelhetők a frissdiplomások fizetéseiben. Annak érdekében, hogy egy homogénebb és egy a gazdasági folyamatokhoz jelentősen hozzájáruló csoport kerüljön be az elemzésbe, kizárólag a frissdiplomás közgazdászok bérét vizsgáltam meg. Ehhez kapcsolódóan egy főhipotézist és három alhipotézist fogalmaztam meg (3. táblázat).

A H1 hipotézist elfogadom, amennyiben az alhipotézisek közül legalább kettő igazolni tudja a regionális tényező hatását és erősségét, és elutasítom, amennyiben csak egy, vagy egyik alhipotézis sem mutatja ki a különbséget. Az egyes régiók közötti különbségek szignifikanciájának vizsgálatára (H1a) az egyutas varianciaanalízis módszerét használom. Amennyiben legalább egy régió 5 százalékos szignifikanciaszinten eltérést mutat bármely más régióval szemben, úgy a hipotézist elfogadom, ellenkező esetben elvetem. A regionális tényező hatásának erősségét a többi, a bér nagyságát potenciálisan befolyásoló tényezőhöz képest (H1b) OLS analízis segítségével vizsgálom meg. Elsőként önmagában a

3. táblázat: Hipotézisek

Hypotheses

frissdiplomás közgazdászok esetében.

\begin{tabular}{|c|c|c|}
\hline \multirow{3}{*}{ H1 } & $\mathrm{H} 1 \mathrm{a}$ & $\begin{array}{l}\text { Vannak olyan régiók, amelyek között szignifikáns különbség tapasztalható a } \\
\text { munkabér tekintetében. }\end{array}$ \\
\hline & $\mathrm{H} 1 \mathrm{~b}$ & $\begin{array}{l}\text { A munkaerőpiaci tényezők bevonása csökkenti legnagyobb mértékben a } \\
\text { területi tényező hatását. }\end{array}$ \\
\hline & $\mathrm{H} 1 \mathrm{c}$ & $\begin{array}{l}\text { A munkahely székhelyének a logaritmizált bérre gyakorolt hatása jelentékte- } \\
\text { lenre csökken a további munkaerőpiaci, tanulmányi és szociodemográfiai } \\
\text { tényezők bevonásának hatására. }\end{array}$ \\
\hline
\end{tabular}


munkahely székhelyének helyet adó régió magyarázóerejét és hatását nézem meg, majd pedig azt, hogy milyen mértékben csökken ez a hatás a munkaerőpiaci, vagy a tanulmányi, illetve a szociodemográfiai tényezők bevonásával. Elfogadom a hipotézist, amennyiben a regionális hatás a további munkaerőpiaci változók modellbe való bevonása esetén lesz a legalacsonyabb. A H1c hipotézis vizsgálatához szintén regressziós módszert használok, és elutasítom, amennyiben az egyes régiók az összes további kiválasztott tényező bevonása mellett is szignifikáns különbséget indukálnak a referencia-kategóriához képest.

\section{Adatbázis és a módszertan bemutatása}

A Diplomás Pályakövetési Rendszer (DPR) Frissdiplomások 2011-2015 közötti felmérései során a kitöltésekkel 111318 adatsor jött létre. Annak érdekében, hogy a kutatás szempontjából releváns adatokkal tudjak dolgozni, több szűrést is végrehajtottam az adatbázison. Az elemzésembe kizárólag a gazdaságtudomány területén diplomát szerzett, nem külföldi településen található munkahellyel rendelkező kitöltők kerültek be, akik olyan munkát végeznek, amely legalább részben megfelel a tanulmányaiknak, illetve megadták fóállásuk normál nettó havi keresetét. A havi nettó bér 60,6 ezer forint alatti értékeit is kivontam az elemzés alól, hiszen az adatok felvételének első évében (2011) ez volt a nettó minimálbér összege, így fóállásban nem reális az ennél alacsonyabb kereset. Ezen feltételek beállításával 12429 adatsor maradt az elemzések elvégzéséhez.

4. táblázat: Adatok megoszlása és átlagos nettó bérek az eredeti és szűrt adatbázisban - DPR Frissdiplomások 2011-2015

Distribution of data and average net wages in the original and filtered database - Fresh Graduates 2011-2015

\begin{tabular}{ccc} 
Felméréséve & Eredeti adatbázis & Szürt adatbázis \\
\hline 2011 & $18,4 \%$ & $17 \%$ \\
2012 & $22,4 \%$ & $20,1 \%$ \\
2013 & $21,8 \%$ & $22,7 \%$ \\
2014 & $19,0 \%$ & $18,3 \%$ \\
2015 & $18,5 \%$ & $21,8 \%$ \\
\hline Összesen & $111318 \mathrm{fó}$ & $12429 \mathrm{fó}$ \\
\hline Felmérés éve & Eredeti adatbázis & Szürt adatbázis \\
\hline 2011 & $157708 \mathrm{Ft}$ & $175969 \mathrm{Ft}$ \\
2012 & $175464 \mathrm{Ft}$ & $189496 \mathrm{Ft}$ \\
2013 & $183582 \mathrm{Ft}$ & $194441 \mathrm{Ft}$ \\
2014 & $196509 \mathrm{Ft}$ & $210438 \mathrm{Ft}$ \\
2015 & $207472 \mathrm{Ft}$ & $219016 \mathrm{Ft}$ \\
\hline Teljes idöszak & $184330 \mathrm{Ft}$ & $198590 \mathrm{Ft}$
\end{tabular}


Az adatbázist az SPSS szoftverrel elemeztem, az egyutas varianciaanalízis (One-Way ANOVA) és a többlépcsős regressziós modell segítségével. Az egyutas varianciaanalízis módszerével több független változó középértéke hasonlitható össze, ez a két mintás t-próba általánosítása. A várható értéket hasonlítja össze a teljes varianciával, tehát több csoport összevetése esetén tulajdonképpen a csoportok eloszlásának összehasonlítása. Feltételei, hogy a minták függetlenek és normális eloszlásúak legyenek, illetve, hogy a minták azonos varianciájú populációból származzanak, azaz körülbelül ugyanakkora szórással rendelkezzenek (Mitev, Sajtos 2007). Ezzel a módszerrel a régiók közötti fizetésbeli különbségek szignifikanciáját fogom megvizsgálni. A regresszió módszerével arra a kérdésre kapható válasz, hogy milyen függvény segítségével tehetünk előrejelzést az egyik változó Y értékére, a másik változó X értékének ismeretében (Mitev, Sajtos 2007). Az OLS modell segítségével több változó bevonásával fogom megvizsgálni, hogy az egyes tényezők hogyan hatnak a nettó logaritmizált bérre.

\section{Az empirikus kutatás eredményei}

\section{Adatelemzés az egyutas varianciaanalízis módszerével}

Az egyes régiók közötti fizetésbeli különbségek mértékének azonosításához első körben az egyutas varianciaanalízis módszerét használtam. A Welch-próba során, amely egy robosztus teszt a szórásegyezőség vizsgálatára, a p érték 0,05-nél alacsonyabb értéket mutat, így elvethetjük a nullhipotézist, mely szerint a szórások nem egyeznek meg. Az ANOVA táblából kiolvasható szignifikancia szint szerint $(\mathrm{p}=0,000)$ van szignifikáns különbség az egyes régiókban kapott fizetések között. Az elemzés szerint a Közép-Dunántúl régióban kapott fizetések értéke pozitív irányban szignifikánsan különbözik az összes többi régió értékeitől, leszámítva a Közép-Magyarország régiót, amellyel szintén szignifikánsan különbözik, de negatív irányba. Közép-Magyarország régiója minden másik régióval szemben szignifikáns különbséget mutat, és minden esetben ebben a régióban magasabb a nettó fizetések értéke. A Nyugat-Dunántúl, Dél-Dunántúl, Észak-Magyarország, Észak-Alföld és Dél-Alföld régiók egymással szemben nem, csak a korábban említett két régióval szemben mutatnak szignifikáns különbséget. A pontos értékek az 5. táblázatban láthatóak, a szignifikáns eltéréseket pedig csillag jelöli. Az elemzés eredményeinek alapján a H1a alhipotézist elfogadom, tehát vannak olyan régiók, amelyek között szignifikáns különbség áll fenn a nettó (log) bérre nézve. 
5. táblázat: Szignifikáns fizetésbeli különbségek az egyes régiók között Significant wage differences between regions

\begin{tabular}{|c|c|c|}
\hline (I) A munkahely régiója & (J) A munkahely régiója & Atlagos különbség (ezer Ft) (I-J) \\
\hline \multirow[t]{6}{*}{ Nyugat-Dunántúl régió } & Közép-Dunántúl régió & $-18,347^{*}$ \\
\hline & Dél-Dunántúl régió & $-1,691$ \\
\hline & Közép-Magyarország régió & $-69,710^{*}$ \\
\hline & Észak-Magyarország régió & 5,368 \\
\hline & Észak-Alföld régió & 1,124 \\
\hline & Dél-Alföld régió & 4,724 \\
\hline \multirow[t]{6}{*}{ Közép-Dunántúl régió } & Nyugat-Dunántúl régió & $18,347^{*}$ \\
\hline & Dél-Dunántúl régió & $16,656^{*}$ \\
\hline & Közép-Magyarország régió & $-51,363^{*}$ \\
\hline & Észak-Magyarország régió & $23,714^{*}$ \\
\hline & Észak-Alföld régió & $19,471^{*}$ \\
\hline & Dél-Alföld régió & $23,071^{*}$ \\
\hline \multirow[t]{6}{*}{ Dél-Dunántúl régió } & Nyugat-Dunántúl régió & 1,691 \\
\hline & Közép-Dunántúl régió & $-16,656^{*}$ \\
\hline & Közép-Magyarország régió & $-68,019^{*}$ \\
\hline & Észak-Magyarország régió & 7,058 \\
\hline & Észak-Alföld régió & 2,815 \\
\hline & Dél-Alföld régió & 6,415 \\
\hline \multirow[t]{6}{*}{ Közép-Magyarország régió } & Nyugat-Dunántúl régió & $69,710^{*}$ \\
\hline & Közép-Dunántúl régió & $51,363^{*}$ \\
\hline & Dél-Dunántúl régió & $68,019^{*}$ \\
\hline & Észak-Magyarország régió & $75,077^{*}$ \\
\hline & Észak-Alföld régió & $70,833^{*}$ \\
\hline & Dél-Alföld régió & $74,434^{*}$ \\
\hline \multirow[t]{6}{*}{ Észak-Magyarország régió } & Nyugat-Dunántúl régió & $-5,368$ \\
\hline & Közép-Dunántúl régió & $-23,714^{*}$ \\
\hline & Dél-Dunántúl régió & $-7,058$ \\
\hline & Közép-Magyarország régió & $-75,077^{*}$ \\
\hline & Észak-Alföld régió & $-4,244$ \\
\hline & Dél-Alföld régió & $-0,643$ \\
\hline
\end{tabular}




\begin{tabular}{ccc} 
Észak-Alföld régió & Nyugat-Dunántúl régió & $-1,124$ \\
& Közép-Dunántúl régió & $-19,471^{*}$ \\
& Dél-Dunántúl régió & $-2,815$ \\
& Közép-Magyarország régió & $-70,833^{*}$ \\
& Észak-Magyarország régió & 4,244 \\
& Dél-Alföld régió & 3,601 \\
\hline Dél-Alföld régió & Nyugat-Dunántúl régió & $-4,724$ \\
& Közép-Dunántúl régió & $-23,071^{*}$ \\
& Dél-Dunántúl régió & $-6,415$ \\
& Közép-Magyarország régió & $-74,434^{*}$ \\
& Észak-Magyarország régió & 0,643 \\
& Észak-Alföld régió & $-3,601$ \\
\hline
\end{tabular}

*A különbség 5\%-on szignifikáns.

Forrás: Frissdiplomások 2011-2015 adatbázison végzett számitások alapján saját szerkesztés

\section{A regionális tényező hatásának vizsgálata OLS modellek segítségével}

Az egyutas varianciaanalízis elemzésből kiderül, hogy vannak olyan régiók, ahol szignifikánsan eltér a felmérésbe bekerült gazdaságtudományi területen dolgozó munkavállalók bére. A csak a munkahely régiója alapján lefutatott regressziós

6. táblázat: A munkahely székhelyének regionális hatása a nettó (log) munkabérre Regional impact of place of work on net (log) wages

\begin{tabular}{|c|c|c|}
\hline & \multicolumn{2}{|c|}{$\begin{array}{c}M I U \\
\text { Regionális tényezó }\end{array}$} \\
\hline $\mathrm{R} 2$ & \multicolumn{2}{|c|}{0,144} \\
\hline Korrigált R2 & \multicolumn{2}{|c|}{0,144} \\
\hline Sig. & \multicolumn{2}{|c|}{0,000} \\
\hline Durbin-Watson & \multicolumn{2}{|c|}{1,504} \\
\hline $\mathrm{F}$ & \multicolumn{2}{|c|}{325,774} \\
\hline Elemszám & \multicolumn{2}{|c|}{11518,000} \\
\hline \multirow[t]{4}{*}{ Konstans } & \multicolumn{2}{|c|}{5,325} \\
\hline & \multirow{2}{*}{\multicolumn{2}{|c|}{$\begin{array}{c}\text { Mo } \\
\text { munkaeröpiac }\end{array}$}} \\
\hline & & \\
\hline & Stand. (B) & Sig. \\
\hline Munkahely régiója Nyugat-Dunántúl (Közép-Magyarország) & $-0,217$ & 0,000 \\
\hline Munkahely régiója Közép-Dunántúl (Közép-Magyarország) & $-0,138$ & 0,000 \\
\hline Munkahely régiója Dél-Dunántúl (Közép-Magyarország) & $-0,197$ & 0,000 \\
\hline Munkahely régiója Észak-Magyarország (Közép-Magyarország) & $-0,173$ & 0,000 \\
\hline Munkahely régiója Észak-Alföld (Közép-Magyarország) & $-0,187$ & 0,000 \\
\hline Munkahely régiója Dél-Alföld (Közép-Magyarország) & $-0,230$ & 0,000 \\
\hline
\end{tabular}

Forrás: Frissdiplomások 2011-2015 adatbázison végzett számítások alapján saját szerkesztés 
modell értékei szerint, a korrigált $\mathrm{R}^{2}$ alapján kizárólag a munkahely elhelyezkedése 14,4 százalékban magyarázza a bér nagyságát. A referencia tényező a legnagyobb elemszámmal rendelkező Közép-Magyarország régió, melynél minden régióban alacsonyabb a munkajövedelem. A regressziós együttható értékének százalékos értelmezése alapján, az egyes régiókban a Közép-Magyarország régió értékénél 13,8-23 százalékkal volt alacsonyabb a vizsgált személyek körében az elért munkajövedelem, az összes többi változó változatlansága esetén.

A teljes több lépcsős regressziós modellbe három lépésben (M1, M2, M3) vontam be a tényezőcsoportokat, a teljes OLS modell egyenlete a következőképpen írható fel:

$$
\mathrm{Y}=\beta_{0}+\beta_{1} X_{1}+\beta_{2} X_{2}+\cdots+\beta_{9} X_{9}+\beta_{10} Z_{1}+\cdots+\beta_{17} Z_{8}+\beta_{18} W_{1}+\cdots+\beta_{23} W_{6}+\varepsilon
$$

ahol $\mathrm{X}_{1} \mathrm{X}_{10}$ jelölik a munkaerőpiaci változókat, $\mathrm{Z}_{1}-\mathrm{Z}_{8}$ jelöli a tanulmányi, $\mathrm{W}_{1}-\mathrm{W}_{6}$ pedig a szociodemográfiai változókat, $\varepsilon$ pedig a hibatag. Ezen változók részletesen a 7. táblázatban láthatóak. A modellben függő változóként a logaritmikus bér szerepel. Az egyes tényezőknél, ahol kettő vagy több opció lehetséges, úgynevezett dummy változókat hoztam létre, 0 számmal jelölve a referenciakategóriát, melyhez képest a többi változó eltérése megjelenik. A referenciakategória neve zárójelben szerepel az elemzést tartalmazó 7. táblázatban az egyes kategóriák megnevezése mögött. A modellbe elsőként csak a munkaerőpiaci változókat vontam be (M1), mely magában foglalja többek között a munkahely régiójának változóját, a munkahely méretét, szakterületét és a munkavállaló státuszát is. Az M2 tényezői között a tanulmánnyal kapcsolatos adatok jelennek meg, mint például a képzési szint vagy a képzés finanszírozási formája. A modell harmadik részébe (M3) kerültek be az olyan szociodemográfiai adatok, mint például a munkavállaló neme.

Az OLS modell magyarázó ereje az egyes tényezőcsoportok bevonásával folyamatosan nőtt, legnagyobb mértékben az elsőként vizsgált munkaerőpiaci tényezők határozzák meg a bér összegét, az M1 modell magyarázóereje 45,7\%. A legnagyobb eltérés $(23,1 \%)$ a középvezetők, illetve a diplomás beosztott alkalmazottak bére között alakul ki, és hasonlóan magas, 22,5\% bérelőny mutatkozik a külföldi tulajdonú cégek javára a teljes mértékben magyar tulajdonban lévő cégekkel szemben. A munkahely régiója 11,2-18,2 százalékos különbséget generál. Bérhátrány mutatkozik a mikro-, kis-és középvállalkozások esetében, bérelőny pedig az 1000 főnél is többet foglalkoztató vállalkozásoknál, a nagyvállalatokat referenciakategóriának véve. A munkaerőpiaci változókat tartalmazó modellben a munkahely teljes köz- vagy magántulajdonúságát jelölő tényezőt leszámítva, minden változó szignifikáns. A tanulmányi tényezők bevonásával a modell (M2) magyarázó ereje 50,7 százalékra nőtt. Ezen modell esetében az újonnan bevont változók közül legnagyobb mértékben a végzés óta eltelt időtáv lett meghatározó, az öt évvel korábban végzettek 17,9, a három évvel korábban végzettek pedig 11,1 százalékkal keresnek többet, az egy évvel a kitöltés előtt diplomát szerzett mun- 


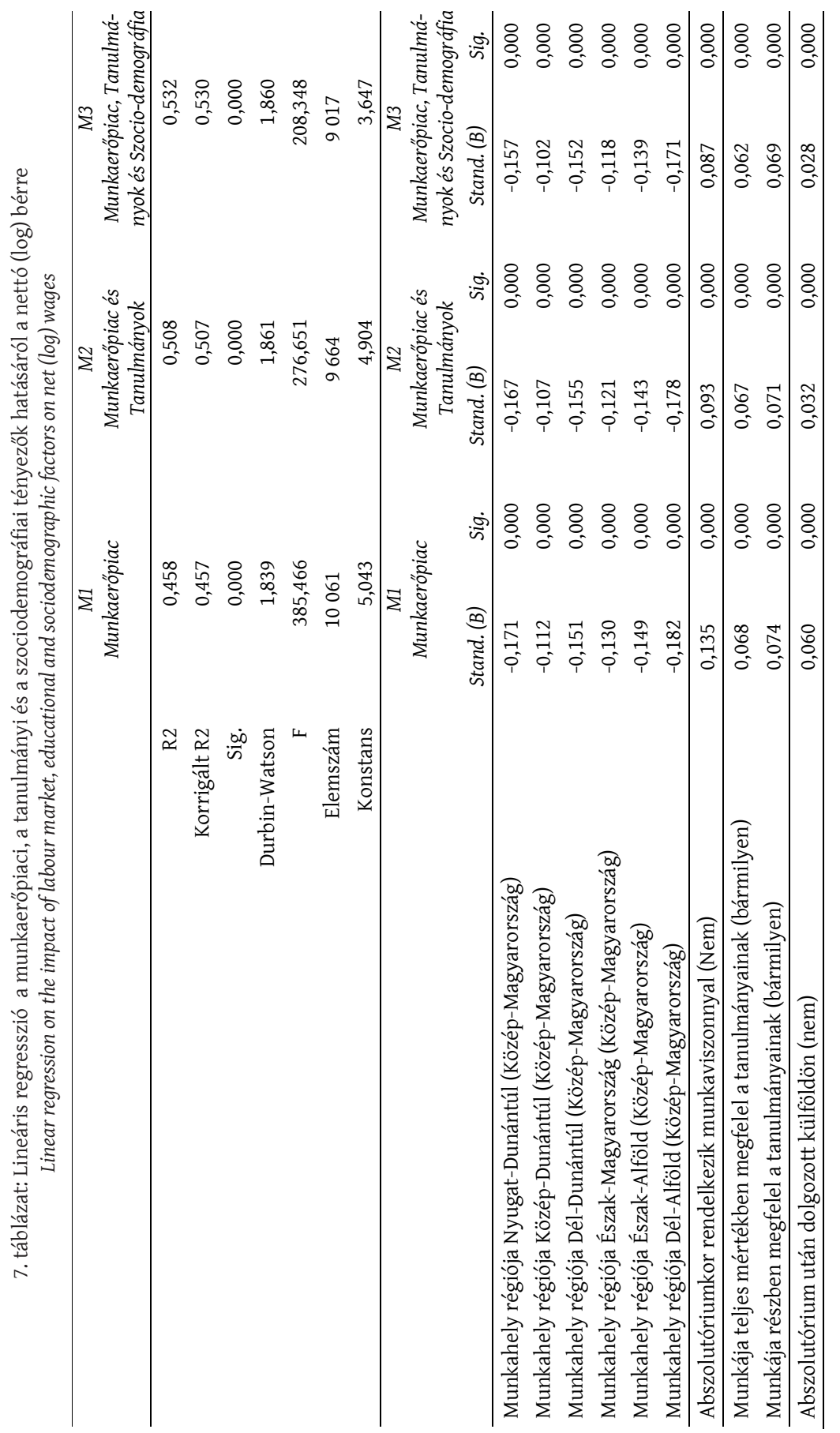




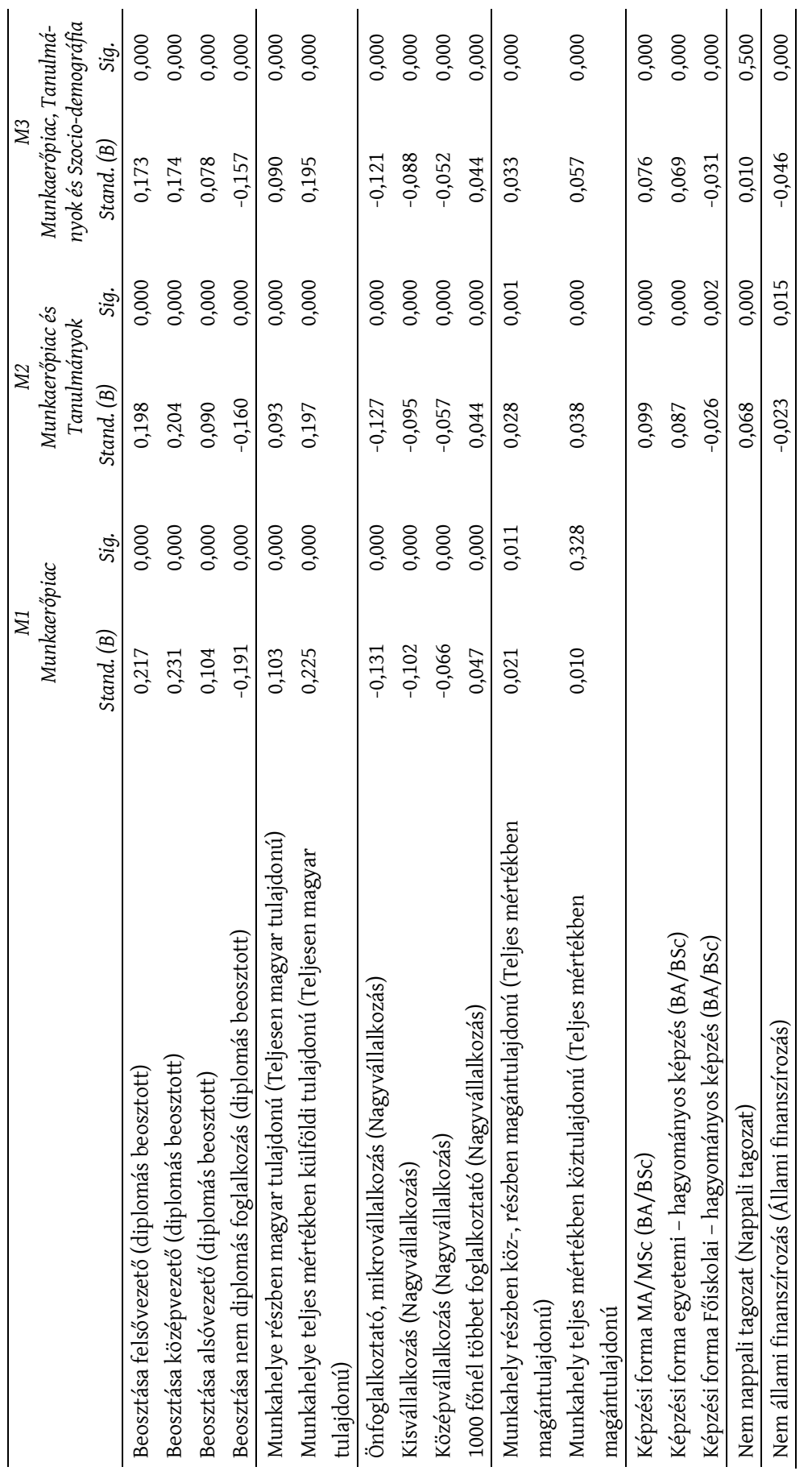




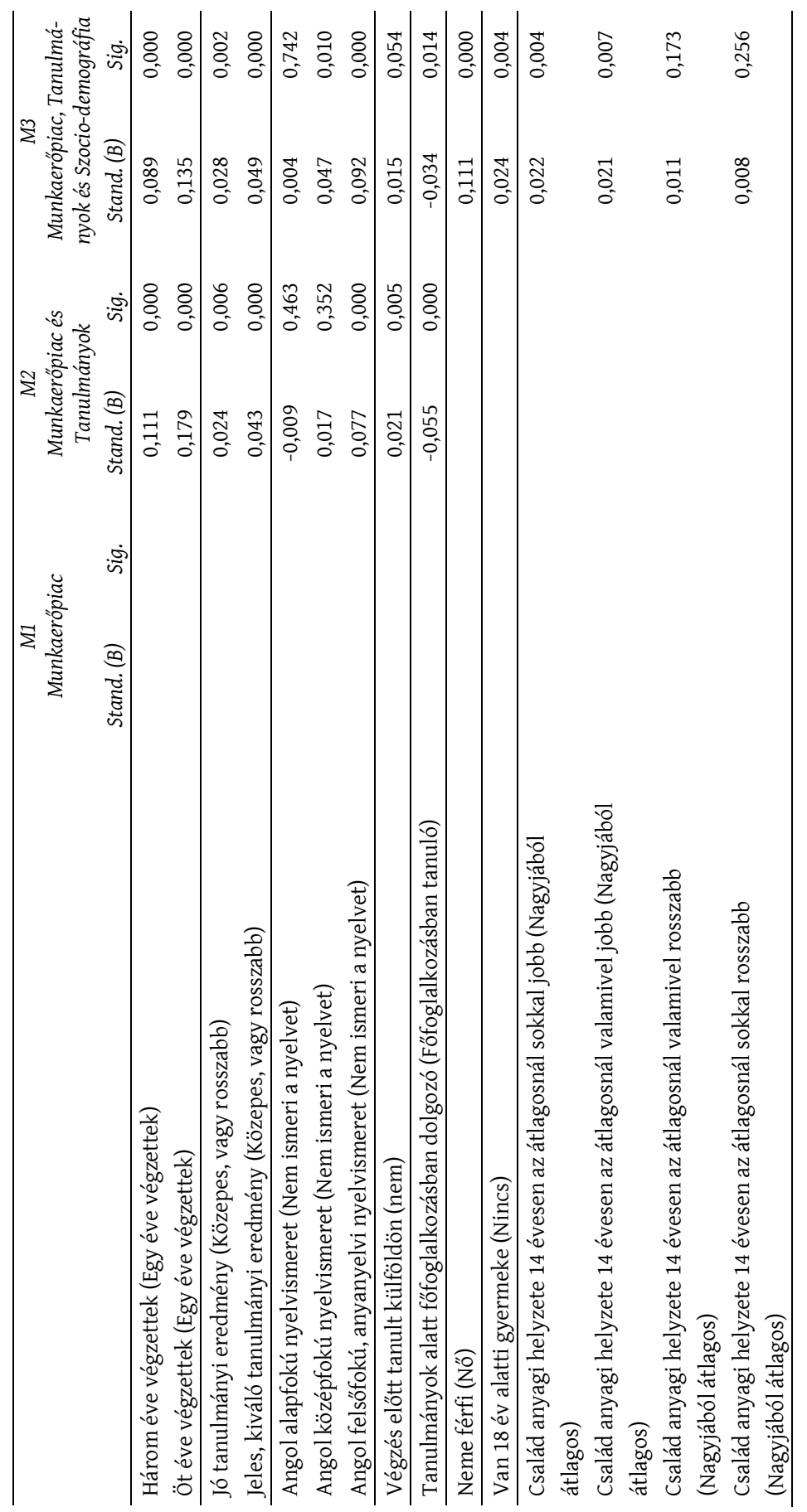




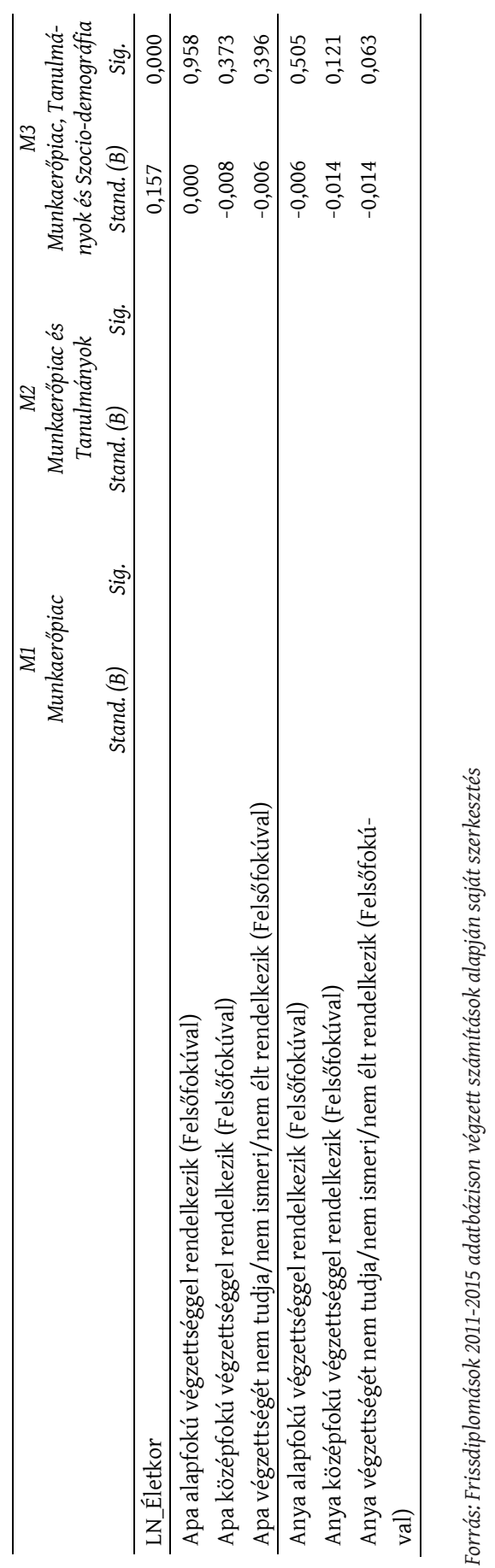


kavállalók. Szintén bérelőnyhöz vezet a munkaerőpiacon a magasabb szintű vagy hosszabb (hagyományos egyetemi) képzés az alapképzéshez képest. Az M3 modell esetében a munkaerőpiaci és tanulmányi helyzetet vizsgáló tényezők mellé bekerületek olyan szociodemográfiai alapadatok is, mint például a nem vagy az életkor. A minden vizsgált tényezőt tartalmazó modell magyarázóereje 53\%, a leghangsúlyosabb tényezők továbbra is az első körben bevont munkaerőpiaci változók közül a beosztás és a munkahely régiója. A szakirodalommal összhangban (Európai Parlament 2020; Szabó-Morvai 2019) ezen adatelemzés során is látható a férfiak számára kialakuló (11,1 százalékos) bérelőny, illetve hangsúlyos az életkor tényezője is, az egy évvel idősebbek 15,7 százalékkal keresnek többet. A teljes OLS modell eredményei a 7. táblázatban láthatóak. Az eredmények igazolják azt a feltevést, hogy a munkahely regionális elhelyezkedése nagymértékben magyarázza az egyén nettó bérjövedelmének nagyságátt, így a H1c alhipotézist elutasítom.

Annak felmérésére, hogy a korábban bemutatott, a bérekre potenciálisan hatással lévő egyes tényezőknek mekkora ereje van, és ezek milyen mértékben csökkentik a regionális tényező hatását, szintén regressziós módszert használtam, és elsőként az egyes tényezőcsoportok hatását külön-külön vizsgáltam meg. Az M1a modell esetében a regionális tényező hatása mellett további munkaerőpiaci változók szerepeltek, a modell egyenlete így írható fel:

$$
\mathrm{Y}=\beta_{0}+\beta_{1} X_{1}+\beta_{2} X_{2}+\cdots+\beta_{9} X_{9}+\varepsilon
$$

Az M2a modell a régió tényezőjén kívül a tanulmányi változókat tartalmazza, így annak egyenlete a következőképpen írható fel:

$$
\mathrm{Y}=\beta_{0}+\beta_{1} X_{1}+\beta_{2} Z_{1}+\cdots+\beta_{10} Z_{8}+\varepsilon
$$

Az M3a modell a szociodemográfiai tényezőket tartalmazza a regionalitáson kívül:

$\mathrm{Y}=\beta_{0}+\beta_{1} X_{1}+\beta_{2} W_{1}+\cdots+\beta_{7} W_{6}+\varepsilon$

Bár a több tényező bevonása valamelyest mindenképp csökkenti a regionalitás magyarázóerejét, látható, hogy a legmagasabb magyarázó erejű M1a modellben jóval nagyobb mértékben csökkent a regionalitás hatása a munkabérre, mint a másik két modell esetében. Az M1a modell magyarázó ereje közel kétszerese az M2a és M3a modellekének, azaz leginkább a munkaerőpiaci tényezők azok, amelyek meghatározzák az egyén bérezését, sokkal kevésbé és közel azonos szinten fontosak az egyéb tanulmányi és szociodemográfiai tényezők. Ennek értelmében a H1b alhipotézist elfogadom, hiszen valóban a munkaerőpiaci tényezők azok, amelyek képesek lehetnek valamilyen szinten kiküszöbölni, redukálni a regionális hatást. A OLS analízisek eredményeit a 8. táblázat tartalmazza. 


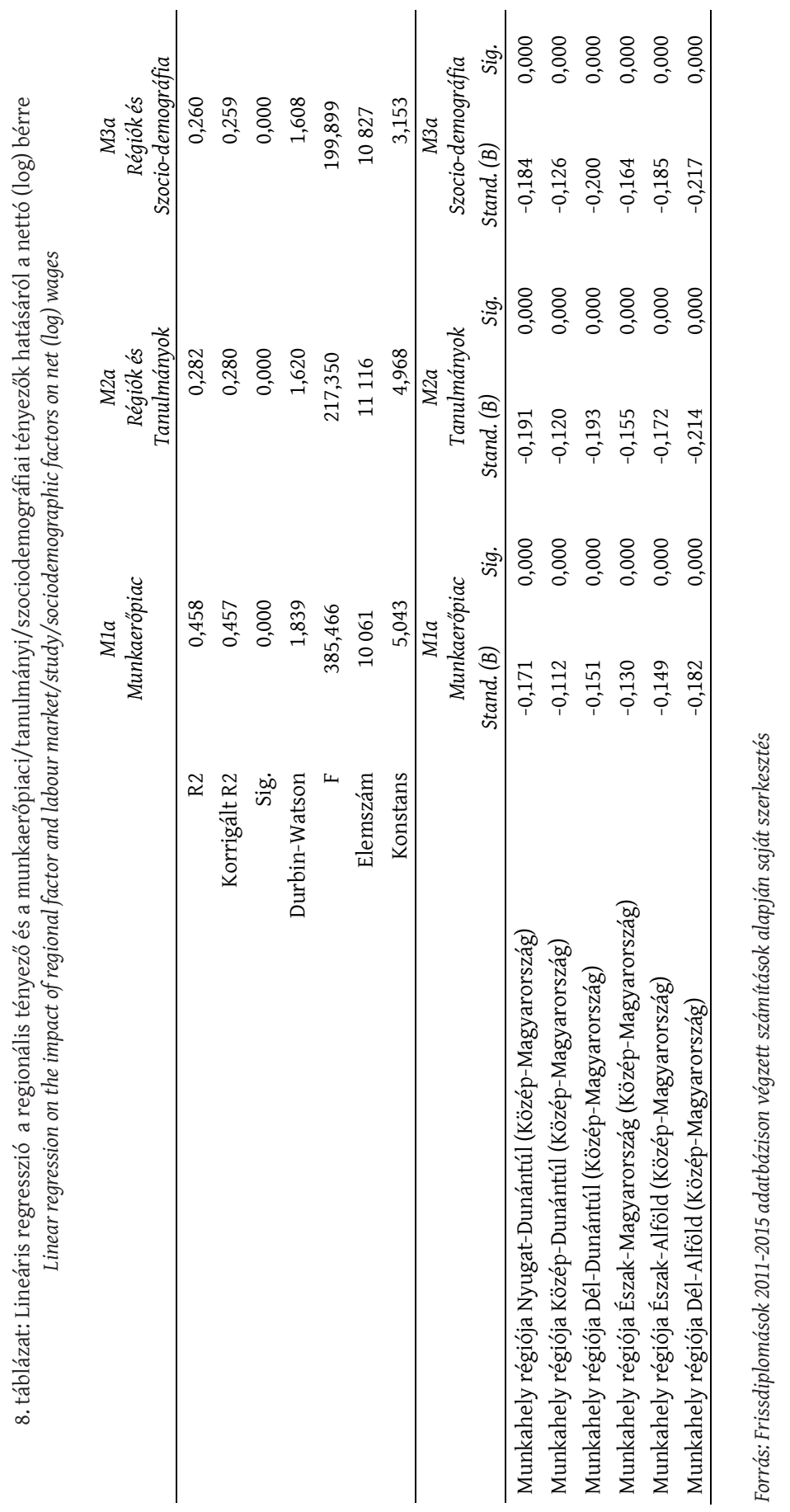




\section{Következtetések}

A kutatás tanulságait összegezve elmondható, hogy ugyan humán tőkénk fejlesztésével (például a felsőoktatási végzettség megszerzésével) rengeteget tehetünk a magasabb munkajövedelem elérése érdekében, számos más tényező is, például a nem, az életkor, vagy a munkahely mérete is nagymértékben befolyásolhatja a fizetés nagyságát. A kutatásom fókuszába helyezett regionális tényező az elemzések során kiemelten fontos munkaerőpiaci tényezőnek minősült, így a H1 hipotézist is elfogadom. Az elemzések alapján a Közép-Magyarország és Közép-Dunántúl régiók fizetésadatai pozitív irányban, szignifikánsan eltérnek a többi régió értékeitől. E két régió egymástól is szignifikánsan eltér, a Közép-Magyarország régióban a legmagasabb az átlagos jövedelem. A bérjövedelmet potenciálisan befolyásoló munkaerőpiaci, tanulmányi, illetve szociodemográfiai változók vizsgálatát regresszió segítségével, OLS modell létrehozásával vizsgáltam. A regionális tényező önmagában 14,4 százalékban magyarázza a munkabér nagyságát. Az egyes változócsoportok külön-külön történő bevonása során kiderült, hogy legnagyobb mértékben a munkaerőpiaci tényezők növelik a modell magyarázó erejét (45,7 százalékara), és csökkentik ezzel együtt a regionális tényező hatását (átlagosan 4,12 százalékkal).

Az összes változót tartalmazó modell esetében az M1 (munkaerőpiaci tényezőket tartalmazó), az M2 (munkaerőpiaci és tanulmányi változókat tartalmazó) és az M3 (a korábbiak mellett szociodemográfiai adatokat is figyelembe vevő) modellek magyarázó ereje a vizsgálat során folyamatosan nőtt, 45,7 százalékról 53 százalékra. A munkahely regionális elhelyezkedésének hatása az egyre több tényező bevonásával is végig jelentős és szignifikáns maradt, viszont hasonló mértékben befolyásolja a munkajövedelem nagyságát a végzés óta eltelt idő, vagy az illető neme, életkora és beosztása. A referencia-változóhoz (Közép-Magyarország) képest az M3 modell eredményeiben 10,2-17,1 százalékkal kapnak alacsonyabb fizetést a más régióban dolgozó munkavállalók. A nők esetében a bérhátrány 11,1 százalékos, míg az öt évvel a felmérés éve előtt végzettek 13,5 százalékos bérelőnnyel rendelkeznek a felmérés előtt csupán egy évvel diplomát szerzett munkavállalókkal szemben, továbbá jelentős az életkor hatása $(15,7 \%)$ is. A közép- és felsővezetők több mint 17 százalékkal keresnek többet, mint a diplomás beosztottak.

Miközben a munkabért több, gyakran az emberek személyes hatáskörén kívül álló tényező alakítja, a fiatal munkavállalóknak a várható bérjövedelem maximálása érdekében érdemes felmérni leendő munkahelyük területi és tulajdoni jellemzőit, illetve méretét és elhelyezkedését az álláskeresés során.

A kutatás korlátja, hogy az elemzést a 15-20 százalékos válaszadási arányú Frissdiplomások adatbázison végeztem el, amely így nem tartalmazza az összes diplomás közgazdász adatait, és nem is feltétlenül jelenti a tudományterület reprezentatív mintáját. Mindemellett általánosságban szisztematikus torzítás nem áll fenn, illetve a mintaelemszám is megfelelő nagyságú. 
Mind az egyutas varianciaanalízis, mind az OLS elemzés elvégezhető az Adminisztratív Adatbázisok Egyesítése adatbázis jóval magasabb számú adataival is, érdemes továbbá a kutatást kibővíteni az egyes régiók vásárlóerőparitásának bevonásával, hogy látható legyen az eltérő fizetések tényleges értéke. Ezen kívül, bár a modell magyarázóereje viszonylag magas, érdemes további változókat is bevonni az elemzésbe, hogy teljesebb képet kaphassunk a bérjövedelmek alakulásáról. További irányt jelenthet a modell bővítése a felsőoktatási intézmények típusával, vagy akár a konkrét intézmények hatásának vizsgálatával (Sipos 2018), illetve olyan egyéb gazdasági tényezőkkel, mint például az egy főre jutó GDP, a munkatermelékenység, az ágazati szerkezet, vagy az 1000 főre jutó vállalkozások száma. Ugyancsak érdemes az OLS analízis során vizsgálni az egyes soft kompetenciák (Sipos et al. 2020) hatását is az egyén bérezésére.

Jövőbeli vizsgálandó terület az objektív és szubjektív tényezők hatásának vizsgálata is (Takács é.n.). A fizetés nagysága az objektív jólét egyik jó mérőszáma, jóllétünk azonban nem csak objektív, hanem szubjektív tényezőktől is nagymértékben függ. Hiába kereshet valaki sokkal több pénzt például Budapesten, ha nem szeret ott élni, vagy hiába dolgozik magas pozícióban, ha saját egyéni értékrendje nem egyezik a vállalatéval.

\section{Köszönetnyilvánítás}

Jelen tanulmány az Oktatási Hivatal DPR - Frissdiplomások 2011-2015 adatbázisának felhasználásával készült. A dokumentumban foglalt számítások és az azokból levont következtetések kizárólag a szerző szellemi termékei.

A dolgozat az Innovációs és Technológiai Minisztérium ÚNKP-20-1-I kódszámú Új Nemzeti Kiválóság Programjának a Nemzeti Kutatási, Fejlesztési és Innovációs Alapból finanszírozott szakmai támogatásával készült.

\section{Irodalom}

Balogh G. (2015): A regionális tehetséggazdálkodás vizsgálati módszerei a Pécsi Tudományegyetem Közgazdaságtudományi Kar hallgatóinak példáján. Tér és Társadalom, 2., 127-148. https:// doi.org/10.17649/TET.29.2.2664

Corcoran, J., Faggian, A. (2017): Graduate Migration and Regional Development. https://www.elgaronline.com/view/edcoll/9781784712150/9781784712150.00005.xml (Letöltés: 2021.06.29.)

Cummins, R. A. (2000): Personal Income and Subjective Well-Being: A Review. Journal of Happiness Studies, 1., 133-158. https://doi.org/10.1023/A:1010079728426

Dilworth, J. L., Chenoweth, L. C., Engelbrecht, J. (2000): A Qualitative Study of The Money Goals of College Students And Their Parents. Association for Financial Counseling and Planning Education, 2., 33-42.

Diplomántúl.hu (2020): Adminisztratív Adatbázisok Egyesitése https://www.diploman tul.hu/adminisztrativ-adatbazisok-egyesitese (Letöltés: 2020.11.05.)

Diplomás Pályakövető rendszer (é.n.): Frissdiplomások 2011-2015 adatbázis 
Eduline (2019): Magyarországon a második legnagyobb a nemek közötti bérszakadék a diplomások körében. https://eduline.hu/palyakezdes/20190911_Az_OECDben_Magyarorszagon_a_masodik_legnagyobb_a_nemek_kozotti_berszakadek_a_diplomasok_koreben (Letöltés: 2020.10.25.)

Eurostat (2020): Gross domestic product (GDP) at current market prices by NUTS 2 regions. https://ec.europa.eu/eurostat/databrowser/view/nama_10r_2gdp/default/table?lang=en (Letöltés: 2020.10.19.)

Európai Parlament (2020): Hírek - A férfiak és nők fizetése közötti szakadék: okok és megoldási javaslatok. https://www.europarl.europa.eu/news/hu/headlines/society/20200109STO69925/a-ferfiak-esnok-fizetese-kozotti-szakadek-okok-es-megoldasi-javaslatok (Letöltés: 2020. 09. 22.)

Frey, B. S., Stutzer, A. (2001): What Can Economists Learn From Happiness Research? Working Paper Series 80., Institute for Empirical Research in Economics, University of Zurich, Zürich https:// wwz.unibas.ch/fileadmin/user_upload/wwz/00_Professuren/Stutzer_Politische_Oekonmie/Publications/happinesssurveyJEL.pdf (Letöltés: 2020.10.30.)

Furnham, A., Argyle, M. (1998): The Psychology of Money. Routledge, London and New York

g7.hu (2019): Hiába dolgozunk sokat, az átlagbérben nehéz lesz felzárkózni. https://g7.hu/adat/20190722/ hiaba-dolgozunk-sokat-az-atlagberben-nehez-leszfelzarkozni/ (Letöltés: 2020.10.26.)

García-Aracil, A., Van der Velden, R. (2007): Competencies for young European higher education graduates: labor market mismatches and their payoffs. Higher Education, 2., 219-239. https:// doi.org/10.1007/s10734-006-9050-4

Katona H. (2019): Hiába vágysz rá, nem leszel tôle boldog. https://g7. hu/penz/20190509/hiabavagysz-ra-nem-leszel-tole-boldog (Letöltés: 2020.10.10.)

Kiss Á. (é.n.): Miért hat ránk a pénz? (Avagy a pénz szerepe az egyén szintjén) http://eco.u-szeged.hu/ download.php?docID=40107 (Letöltés: 2020.10.21.)

Kosztány Zs. T., Banász Zs. , Csányi V. V., Telcs A. (2020): Diplomás mobilitás vs. Belső migráció Magyar Tudomány, 10., 1318-1331. http://real.mtak.hu/115628/1/Magy.Tud._Diplomas\%20mobilitas\%20vs.\%20belso\%20migracio.pdf (Letöltés: 2021.06.27.)

KSH (2018a): Az összes háztartás adatai a referenciaszemély korcsoportja, iskolaivégzettsége és a háztartástagok korösszetétele szerint (2010-) https://www.ksh.

hu/docs/hun/xstadat/xstadat_eves/i_zhc015b.html?down=1577 (Letöltés: 2020.10.20.)

KSH (2018b): Az összes háztartás adatai jövedelmi tizedek (decilisek), régiók és a települések típusa szerint (2010-) https://www.ksh.hu/docs/hun/xstadat/xstadat_eves/i_zhc014c.html?down=688.7999877929688 (Letöltés: 2020.10.06.)

KSH (2019): A teljes munkaidőben alkalmazásban állók havi bruttó átlagkeresete nemzetgazdasági áganként (2009-) https://www.ksh.hu/docs/hun/xstadat/xstadat_eves/i_qlio12b.html (Letöltés: 2020.10.20.)

KSH (2020): Egy före jutó bruttó hazai termék megye és régió szerint. https://www.ksh.hu/stadat_files/gdp/hu/gdp0078.html (Letöltés: 2021.06.20.)

Kuráth G., Sipos N. (2019): A hazai felsőoktatási jelentkezési döntések változása - A regionális hatás. Tér és Társadalom, 1., 173-184. https://doi.org/10.17649/TET.33.1.3073

Lengyel I., Rechnitzer J. (2004): Regionális gazdaságtan. Dialóg Campus Kiadó, Budapest, Pécs

Lukács R., Rácz I. (é.n.): Magyarország regionális fejlődési különbségei. https://dtk.tankonyvtar.hu/xmlui/bitstream/handle/123456789/4336/lukacs_reka_racz_irma_magyarorszag_regionalis.pdf? sequence=1\&isAllowed=y (Letöltés: 2021. 06. 26.)

Meixner Z. (2011): Feltárták a pénz és a boldogság összefüggéseit. https://hvg.hu/gazdasag/20110202_penz_boldogsag_osszefuggese (Letöltés: 2020.10.11.)

Mitev A., Sajtos L. (2007): SPSS kutatási és adatelemzési kézikönyv. Alinea Kiadó

MNB (2020): Termelékenységi jelentés. https://www.mnb.hu/letoltes/termelekenysegi-jelentes-2020hun.pdf (Letöltve: 2021.06.22.)

Oosterbeek, H., Webbink, D. (2011). Does studying abroad induce a brain drain? Economica, 78., 347-366. https://doi.org/10.1111/j.1468-0335.2009.00818.x

OECD (2015): Recommendation on Gender Equality in Education. https://data.oecd.org/earnwage/gender-wage-gap.htm (Letöltés: 2020.10.25.)

PwC (2017): PwC Women In Work Index - Closing the gender pay gap. https://www.pwc.com/hu/hu/kiadvanyok/assets/pdf/PwC_Women_in_Work_2017_20170208_v2.pdf (Letöltés: 2020. 09. 22.)

PwC (2020): Women in Work. https://www.pwc.co.uk/womeninwork (Letöltés: 2020. 09. 22.) 
Rigó A. (2017): Kis cégnél vagy, ahol csak álom a jó fizetés? Nem vagy egyedül! https://www.portfolio.hu/ gazdasag/20170202/kis-cegnel-vagy-ahol-csak-alom-a-jofize tes-nem-vagy-egyedul-243390\# (Letöltés: 2020.10.26.)

Schultz, W. T. (1961): Investment in Human Capital.The American Economic Review, 51 (1) (March), 1-17. http://www.jstor.org/stable/1818907?origin=JSTOR-pdf (Letöltés: 2020.10.13.)

Schultz, W. T. (1983): Beruházás az emberi tókébe. Közgazdasági és Jogi Kiadó, Budapest

Sipos N. (2018): Frissdiplomás kereseti egyenlő(tlen)ségek a hazai felsőoktatási intézmények függvényében. Marketing \& Menedzsment, 1., https://un ivpecsmy.sharepoint.com/personal/sinmaak_pte_tr_pte_hu/Documents/Microsoft\%20Teams\%20Chat\%20Files/Sipos_MM_2018_1.pdf (Letöltés:2020.11.07.)

Sipos N., Balogh G., Kuráth G. (2013): A kompetenciák, mint a frissdiplomások bérét befolyásoló tényezők a Pécsi Tudományegyetem példáján. Educatio, 4., 589-596. https://www.researchgate.net/ublication267034446_A_kompetenciak_mint_a_frissdiplomasok_beret_befolyasolo_tenyezok _a_Pecsi_Tudomanyegyetem_peldajan (Letöltés:2020.10.26.)

Sipos N., Kuráth G., Gyarmatiné Bányai E. (2020): A frissdiplomások kompetenciái és a bérek kapcsolata. Közgazdasági Szemle, LXVII. évf., 2020. november, 1130-1153. https://doi.org/10.18414/ KSZ.2020.11.1130

Stevenson, B., Sacks, D. W.,Wolfers, J. (2010): Subjective well-being, income, economic development and growth. National Bureau of Economic Research, Working Paper 16441 https://www.nber.org/ papers/w16441.pdf (Letöltés: 2020.10.14)

Szabó L. (2017): NŐK VS. FÉRFIAK - Bérkülönbségek a 21. században. https://juratus.elte.hu/nok-vs-ferfiak-berkulonbsegek-a-21-szazadban (Letöltés: 2020. 09. 22.)

Szabó-Morvai Á. (2019): Nók a munkaerőpiacon - okok és következmények. MTA KRTK, Közgazdaságtudományi Intézet, Budapest http://real.mtak.hu/88812 (Letöltés: 2020.10.25.)

Takács D. (2012): A boldogság közgazdaságtana: A boldogság fogalmáról és mérhetőségéről. In: Hámori B., Vajda B., Tóth L., Derecskei A., Prónay Sz. (szerk.): Érzelmek és indulatok a gazdaságban: A gazdasági szereplók viselkedésének sajátosságai a döntésekben és folyamatokban. Szegedi Tudományegyetem Gazdaságtudományi Kar, Szeged, 517-533. https://eco.u-szeged.hu/download.php?docID=40123 (Letöltés: 2021.02.08.)

Varga J. (1998): Oktatás-gazdaságtan. Közgazdasági Szemle Alapítvány, Budapest 


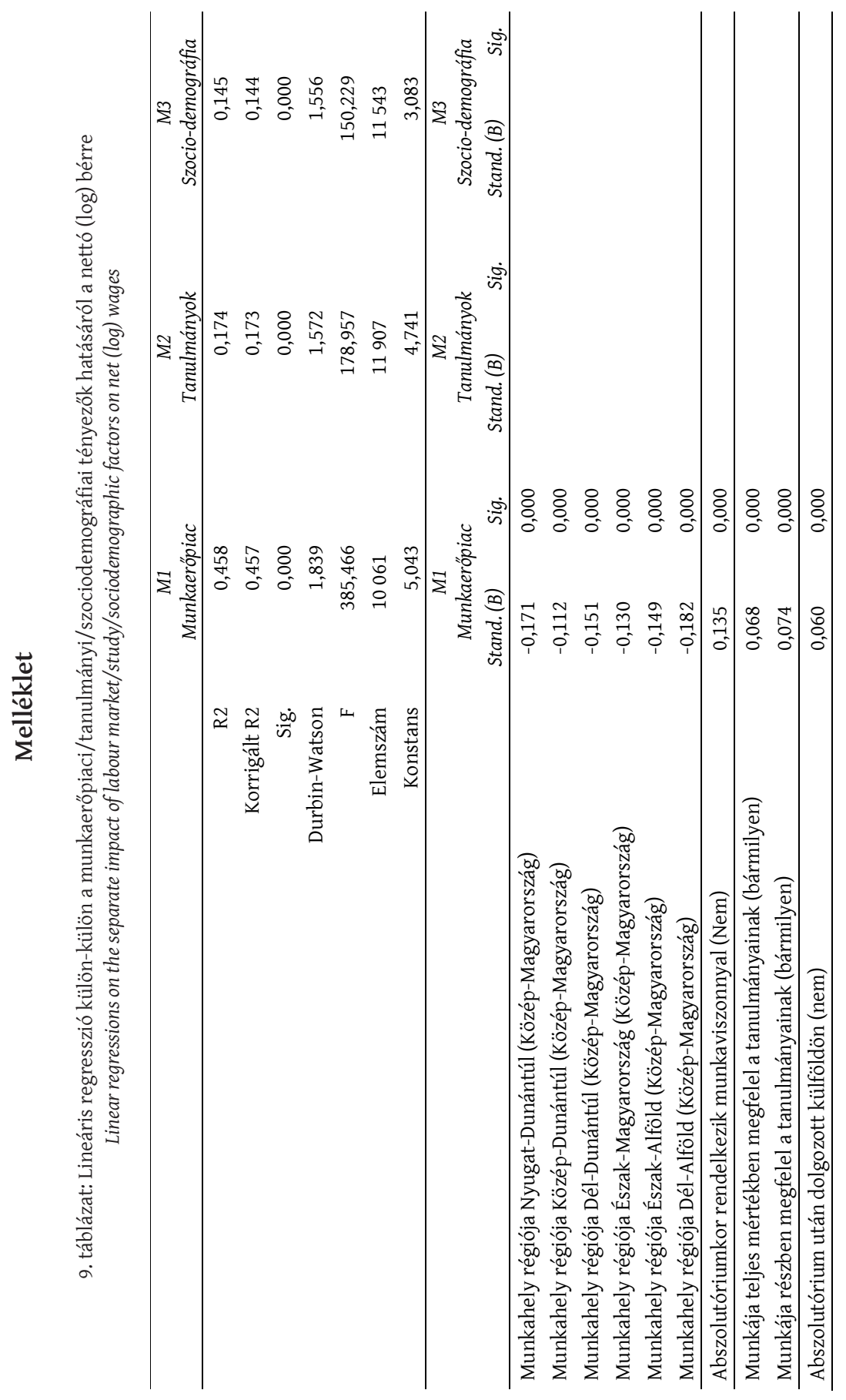




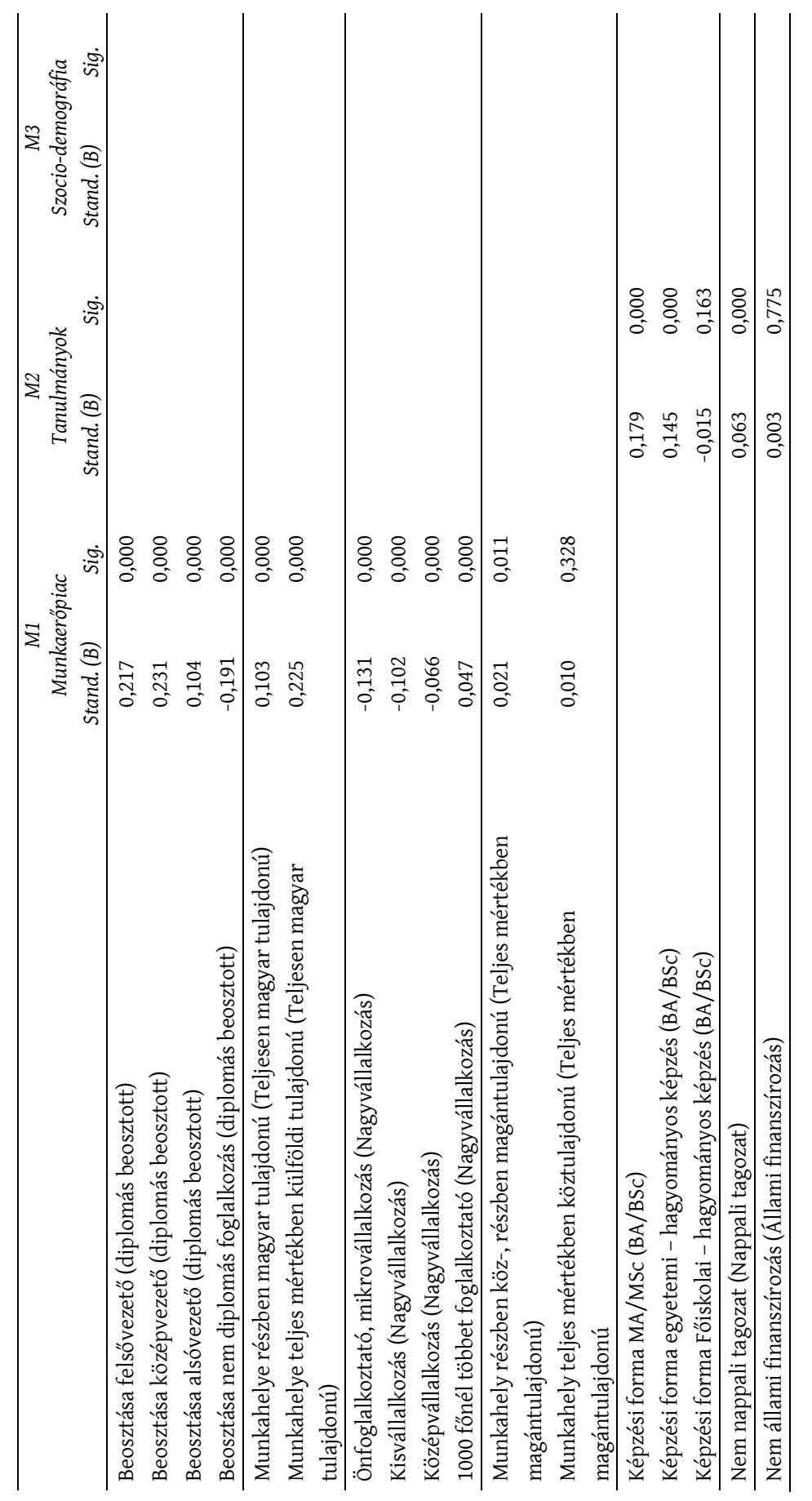


Regionális bérjövedelem-különbségek a gazdaságtudományi területen végzett frissdiplomások... 207

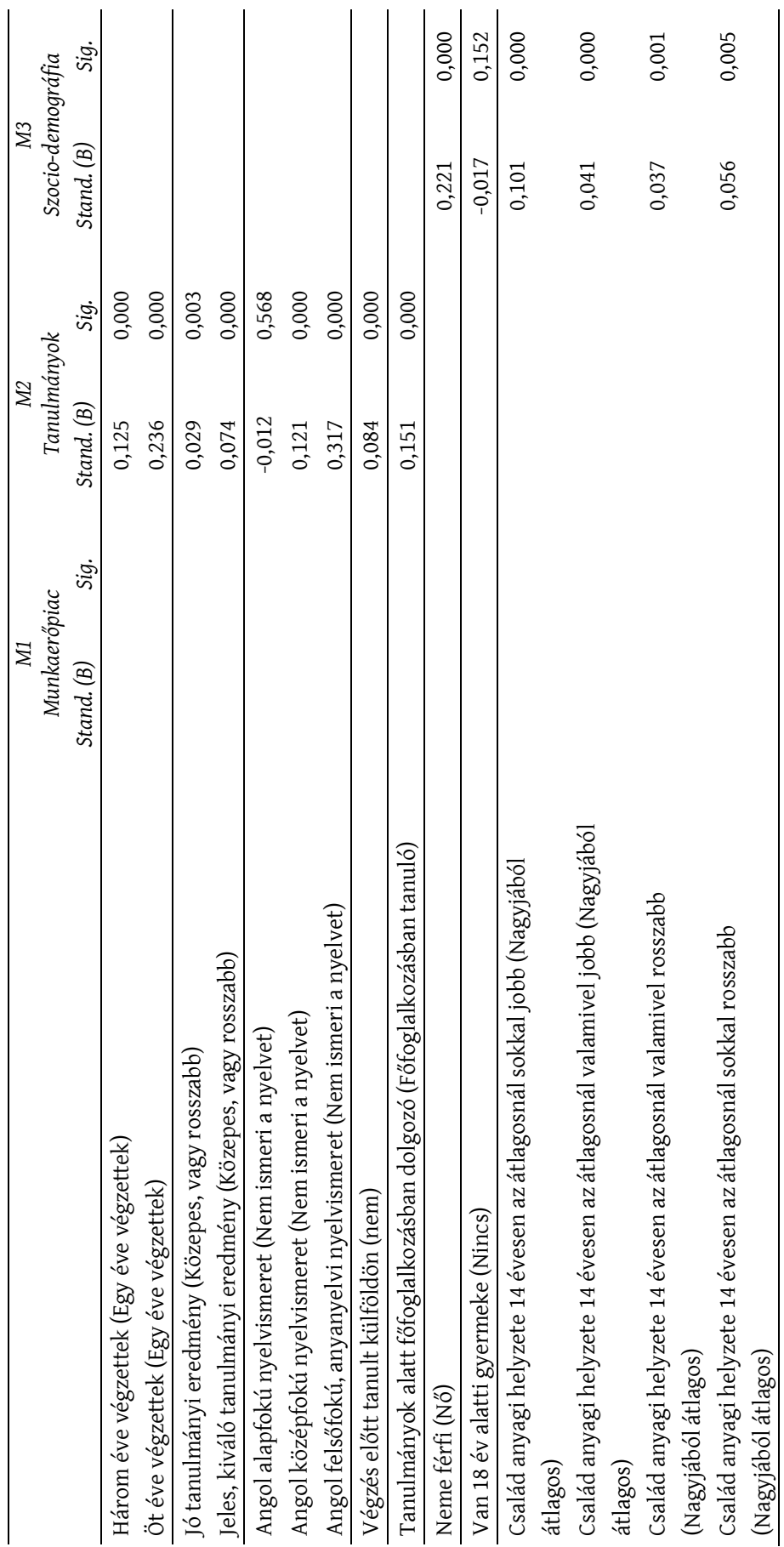




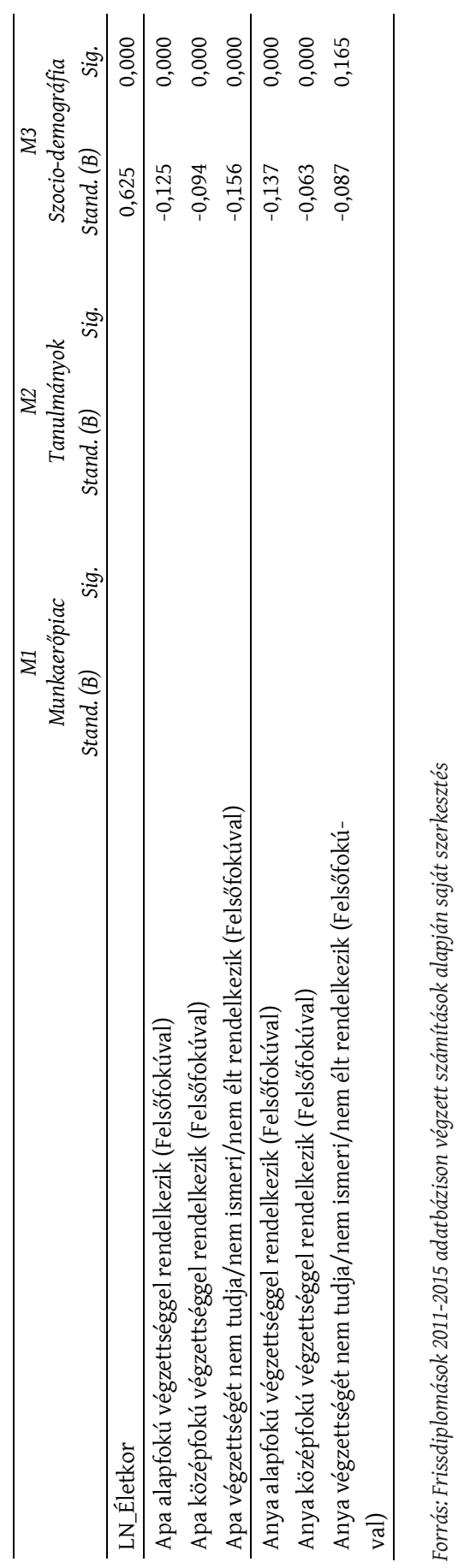

